\title{
AGE STRUCTURE OF LABOUR FORCE AND ITS IMPACT ON WAGES AND PRODUCT
}

\author{
MARTINA ŠIMKOVÁ \\ University of Economics, Prague, Faculty of Informatics and Statistics, \\ Department of Demography, W. Churchill Sq. 4, Prague, Czech Republic \\ email: martina.simkova@vse.cz

\section{LUBOŠ MAREK} \\ University of Economics, Prague, Faculty of Informatics and Statistics, \\ Department of Statistics and Probability, W. Churchill Sq. 4, Prague, Czech Republic \\ e-mail:marek@vse.cz
}

\begin{abstract}
Ageing of population is connected with significant changes in many areas of human life. It influences both social environment and economy, not only in the Czech Republic. Potential impact of the changes of labour force in developed countries is a subject of ongoing research in scientific community. Among all aspects, at least changes of labour productivity may appear because of changes of age structure of labour force. The issue of dependency of labour productivity on age has not been deeply discussed in the Czech Republic up to now. It is also affected by difficult availability of appropriate data. Our contribution provides the guidance how to combine different types of data. Our dataset is based on the combination of data from business statistics, statistical survey on wages and national accounts. The paper estimates the effects of age structure of labour force on level of wages and value added. It also identifies these effects both on level of total economy and particular industries for the Czech Republic between 2005 and 2015. Our findings provide additional information about population ageing to be discussed by policy makers.
\end{abstract}

Key words: ageing of population, average wage, gross value added, labour force

JEL Codes: J14, J31, J82

DOI: 10.15611/amse.2017.20.34

\section{Introduction}

Population ageing influences many areas of human life and economy, while individual ageing is argued to be a success story due to a rising number of years lived in good health. On the contrary, population ageing is commonly associated with negative consequences for the financial sustainability of social security systems. Labour market belongs to the areas where the increasing proportion of older people will be noticeable. They become important part of labour force and they will influence the amount of output created. The labour force ageing will affect the performance of organizations in the forthcoming years, with two temporary consequences - a brain drain and a talent gap. Both the private and the public sector will face a shortage of qualified personnel (Leuprecht, 2010). The ageing labour force means more experience and educated workers in some industries, experts, professors, doctors etc. On the contrary, the decrease in physical and mental abilities can be treated as a serious problem in some industries. The relevant issue lies in the possible influence of population ageing on economic product. 
The paper brings the results of our analysis describing changing in age structure, wages, product and labour productivity in the Czech Republic in the decade 2005-2015. The links between key features of ageing labour force, mainly value added and wages are presented at the level of selected industries. Further, the results are accompanied by the statistical approach to the testing of differences of average wages between age groups. For the purpose of our analysis, we had to combine data from national accounts and business statistics.

\section{Literature review}

The studying of the links between labour force ageing, level of wages and productivity is the subject of many worldwide studies. This issue is viewed from many different perspectives: at national level (e.g. Prskawetz et al., 2007), or industry level (e.g. Kuckulenz, 2006), at organization level (e.g. Göbel, Zwick, 2009) or at individual level (e.g. Skirbekk, 2004) or at occupation level.

The reason for dealing with consequences of labour force ageing is the concern about lower productivity of older workers, lower ability to adopt new technologies, lower potential for economic innovation, professional and occupational mobility. Avolio and Waldman (1994) set at around 30 years the age at which cognitive and physical abilities start to decline, whereas Skirbekk (2004) places around 50 the age at which productivity starts to decline. The decline in the labour productivity along with workers' age has been documented by a number of authors for specific occupations. For example, Diamond (1986) shows the effect of ageing for mathematicians and scientists, Oster and Hamermesh (1998) for economists and Bhattacharya and Smyth (2001) for Australian judges. But the other way around (Posner, 1995) show that judges might be an exception to this phenomenon. He argues that the productivity of judges increases with age as well as their creativity and achievements. Some studies, on the contrary, show a work effort as significant difference between younger and older workers. It means that younger workers spent more time working at the workplace as well as higher level of pace than older workers (Tang and MacLeod, 2006).

In the Czech Republic, the issue of ageing population is discussed in connection with sustainability of pension system and appropriate setting of retirement age (e.g. Sivák et al, 2011 or Fiala, Langhamrová, 2016), availability of social services (e.g. Průša, 2015) or ageing of workers in selected occupations (e.g. Š́dlo, 2011). This paper presents the issue of ageing labour force in relation to output and labour productivity and thus brings different view on the ageing population not discussed up to now in the Czech Republic.

\section{Data and methodology}

Some studies estimate the relationship of productivity and labour force demographics using panel data (e.g. Tang, MacLeod, 2006). However, official data on value added by age are not available in the Czech Republic and no panel data is available. Conducting of data survey on the level of companies would be very difficult and expensive. Moreover, value added on the company level is slightly different than the value added compiled in the framework of national accounts and only national accounts' data ensures comparability of value added between different industries in the economy.

Given that we combine data from business statistics (BS) and national accounts (NA). Similar and complementary data it is possible to obtain from Labour Force Survey (LFS) and statistical survey on wages (AEIS) ${ }^{1}$. As a result, we combine data about value added, wages and salaries, average wage and number of employees and their age. Estimations based on the

1 This survey is labelled as Average Earnings Information System (AEIS), organized by Trexima, see https://www.ispv.cz/en/homepage.aspx 
combination of these data provide satisfactory breakdown of gross value added between groups of employees given by the age threshold. We distinguish five age groups of employees (less than 30,30-39, 40-49, 50-59, 60 and over).

The estimation of value added by age is based on the assumption, that the employees are paid according to their marginal productivity (Elgis, Kuzubas, 2013). Therefore, average wage represents suitable proxy indicator for contribution of employees to value added of companies. This assumption allows us to estimate value added through compensation of employees, resp. wages and salaries ${ }^{2}$. Gross value added based on national accounts' methodology ESA 2010 is within income approach estimated by sum of compensation of employees, other net taxes on production, consumption of fixed capital and net operating surplus (Eurostat, 2013). According to the national accounts theory (with its foundations in Keynesians), compensation of employees represent labour input and the share of employees' contribution to gross value added. We assume that gross valued added is proportionally linked to compensation of employees and the rate of operating profit is the same for all age groups, i.e. both taxes and depreciation of the property (consumption of fixed capital) is not dependent on the age structure of the employees. In other words, compensation of employees (resp. wages and salaries) are main driving factor of value added.

The procedure of estimates consists in the transition from business statistics data to figures in national accounts' methodology. Data on average wages and number of employees by age groups came from business statistics are the first input data. These figures are recalculated to national accounts' methodology ${ }^{3}$. Average monthly wage is an intensity indicator and therefore must be recalculated in the form of absolute amount, i.e. total amount of wages per year (number of employees multiplied by average annual wage). In national accounts' methodology, this item is called wages and salaries. The relative structure of wages and salaries by age groups is applied to official figures on gross value added published by Czech Statistical Office (CZSO). Although all figures are available by 21 industries classified by NACE rev. 2 (CZ-NACE), we selected only some significant industries for clarity.

\section{The changes in the labour force}

Changes in demographic structure in developed countries will have broad consequences for economic sustainability in the following years (Mahlberg et al., 2013). The increase of the number of older people due to low mortality, the reduction of young population due to low fertility and moderate level of migration indicate ageing of population as well as ageing of labour force. In other words, the ability of the labour market for substitution of retired workers with young workers will be reduced. The process of ageing is noticeable on the overall figures on employment ${ }^{4}$ in the Czech Republic. The share of young employees is continuously decreasing. The share of employees in age group less than 30 years has decreased from $19.2 \%$ in 2005 to $15.7 \%$ in 2015. Employees aged between 30 and 50 years has stable 50\% share in total employment. The share of employees older than 60 years has increased from $3.4 \%$ in 2005 to $6.7 \%$ in 2015 (Figure 1). With respect to the assumption by projection about future development of age structures, we can expect continuing increase in the share of older employees.

\footnotetext{
2 We recognize that there is a simplified procedure. The most optimal should be worked hours on the company level, but this indicator has to be converted into money, and there is no data about. It requires some panel data.

${ }^{3}$ Methodology according to ESA 2010. More about the implementation of the new ESA 2010 standard in Sixta, Vltavská, 2016.

${ }^{4}$ With respect to available data sources, we focus on employees only since there is no detailed data about self-employed. This simplification cannot influence our findings.

${ }^{5}$ See https://www.czso.cz/csu/czso/projekce-obyvatelstva-ceske-republiky-do-roku-2100-n-fu4s64b8h4
} 
Figure 1: Age structure of employment in the Czech Republic in 2005 and 2015 (\%)
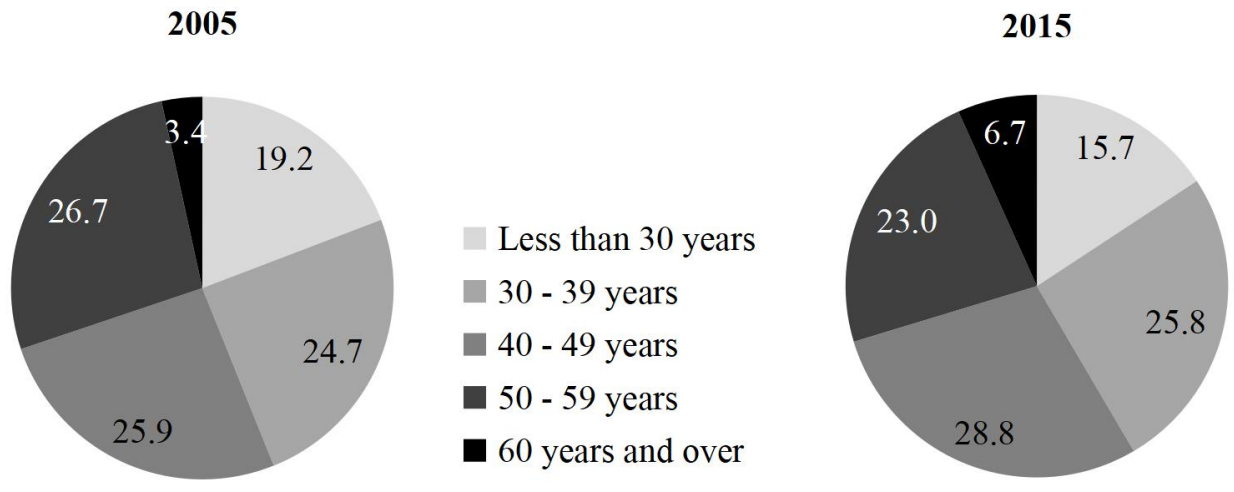

Source: CZSO, authors' calculations

The ageing of employees is significantly different at industry level. Figure 2 shows the share of employees aged 60 years and over in selected industries of Czech economy. Industry of agriculture (A) has the highest increase in the share of employees aged over 60 years between 2005 and 2015 (from 3.9\% to 11.9\%). High proportion of older employees is also seen in total industry (B-E) ${ }^{6}$ and in public administration $(\mathrm{O})$. On the contrary, the share of employees aged over 60 years decreased in Information and Communication ( $\mathrm{J}$ ) by 1.2 p.p. between 2005 and 2015 .

Figure 2: The share of employees aged over 60 years in 2005 and 2015 by selected industries $(\%)$

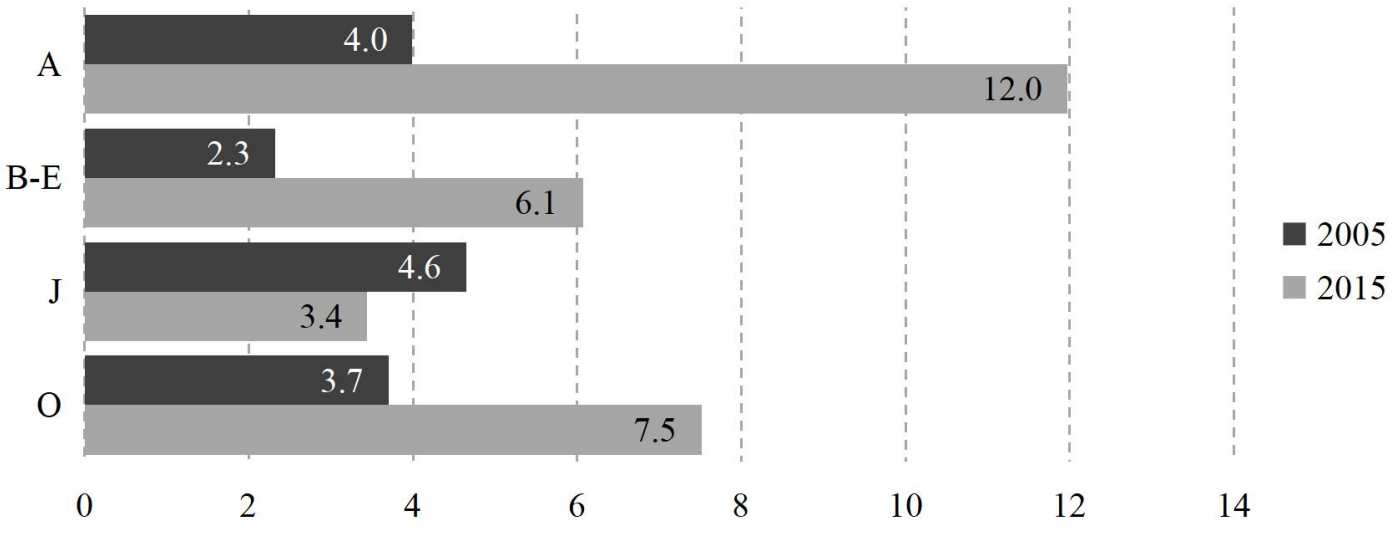

Source: CZSO, authors' calculations

International Labour Organization (ILO) defines ${ }^{7}$ labour force as the sum of employed and unemployed people in the economy. In the analysis, only employees are considered, however the view of unemployment by age is at least interesting (see Figure 3). Age structure of unemployed has been changing at a very slow pace. People aged 60 years and over are very little represented in the total number of unemployed, even though their relative share has been raised from $1.4 \%$ in 2005 to $3.2 \%$ in 2015 .

The reason of low unemployment of people aged 60 years and over is that most of people $\underline{\text { in this age are already economically non-active. Despite economic activity rate of people aged }}$

\footnotetext{
6 Total industry includes industries Mining and Quarrying (B), Manufacturing (C), Electricity, Gas, Steam and Air Conditioning Supply (D) and Water Supply; Sewerage, Waste Management and Remediation Activities (E).

${ }^{7}$ See: http://www.ilo.org/global/statistics-and-databases/statistics-overview-and-topics/WCMS_470304/lang--en/index.htm.
} 
60 years and over has increased as well as rate of people aged $50-59$ years (see Table 1). Economic activity rate of people aged 60 years and over increased by 4.4 p.p. from 2005 to 2015.-

Figure 3: Age structure of unemployed in the Czech Republic 2005 and 2015 (\%)

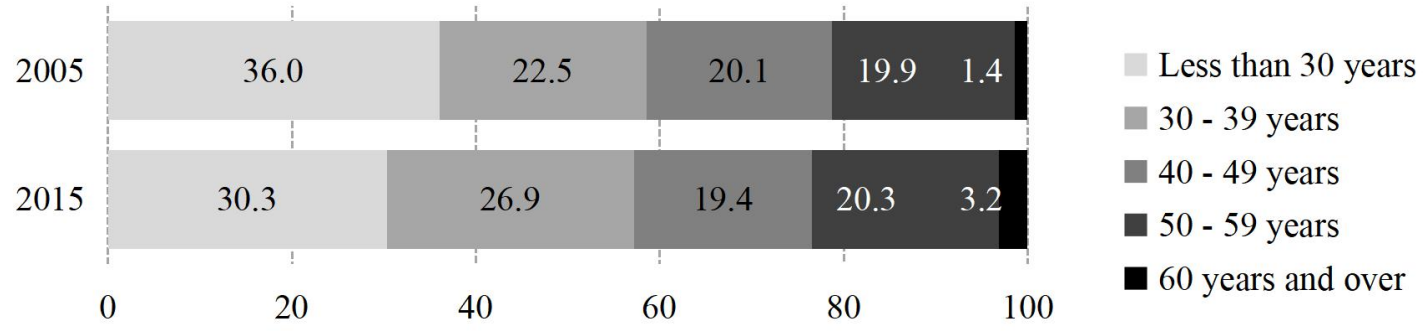

Source: CZSO

The reason of low unemployment of people aged 60 years and over is that most of peoplein this age are already economically non-active. Despite economic activity rate of people aged 60 years and over has increased as well as rate of people aged $50 \quad 59$ years (see Table 1). Economic activity rate of people aged 60 years and over increased by 4.4 p.p. from 2005 to 2015 .

Table 1: Economic activity rates by age in the Czech Republic in 2005 and 2015 (\%)

\begin{tabular}{rrrrrr}
\hline & Less than 30 years & $\mathbf{3 0} \mathbf{- 3 9}$ years & $\mathbf{4 0}-\mathbf{4 9}$ years & $\mathbf{5 0}-\mathbf{5 9}$ years & 60 years and over \\
\hline $\mathbf{2 0 0 5}$ & 51.9 & 88.3 & 93.3 & 77.3 & 9.4 \\
$\mathbf{2 0 1 5}$ & 51.4 & 85.5 & 93.6 & 87.7 & 13.8 \\
\hline
\end{tabular}

Source: CZSO

\section{The factor of age in the structure of wages and gross value added}

Key question is if created value added is influenced by the composition of employees. To this finding the one possibility is to use the amount wages paid to the employees of all age groups in industries and the second possibility is to use the number of employees by age groups and compare these figures with gross value added.

\subsection{The structure of wages by age of employees}

We suppose that the development of economy is also dependent on the quality of its labour force. Although the quality is difficult to measure, we use the amount of wages paid to different age groups as a proxy. We compare the average wages in age groups. Our data has the form of time series (years 2005-2015) with linear trend. Since the average wages are expressed in real amount (at prices of 2015), they assumptions of the analysis of variance (ANOVA) are valid ${ }_{-}^{8}$ This method is the major statistics methods for comparison of our five age groups. The ANOVA table (see Table 2) decomposes the variance of the data into two components: a between-group component and a within-group component. F-ratio, is a ratio of the between-group estimate to the within-group estimate. We worked with five age groups and we tested the equality of means among these groups. From statistical point of view, we tested hypothesis $\mathrm{H}_{0}$ vs. alternative hypothesis $\mathrm{H}_{1}$ at usual level $\alpha=0.05$ :

\footnotetext{
${ }^{8}$ To use the ANOVA the following assumptions are made: each age group sample is drawn from a normally distributed population, data have a common variance, all samples are drawn independently of each other within each sample, the observations are sampled randomly and independently of each other.
} 


$$
\begin{aligned}
& H_{0}: \mu_{1}=\mu_{2}=\mu_{3}=\mu_{4}=\mu_{5}, \\
& H_{1}: \text { non } H_{0},
\end{aligned}
$$

where $\mu_{k}$ is the mean in group $k, k=1, \ldots, 5$.

For confirmation we used Kruskall-Wallis test by ranks. The Kruskal-Wallis verifies the hypothesis that the medians within each of the five age groups is the same. The data from all the groups is first combined and ranked from smallest to largest. The average rank is then computed for the data in each group (see Table 3 ). We tested hypothesis $\mathrm{H}_{0}$ vs. alternative hypothesis $\mathrm{H}_{1}$ at usual level $\alpha=0.05$ :

$$
\begin{aligned}
& H_{0}: \widetilde{x}_{1}=\widetilde{x}_{2}=\widetilde{x}_{3}=\widetilde{x}_{4}=\widetilde{x}_{5}, \\
& H_{1}: \text { non } H_{0},
\end{aligned}
$$

where $\widetilde{x}_{k}$ is median of wages in age group $k, k=1, \ldots, 5$.

Table 2: The results of ANOVA

\begin{tabular}{lrrrrr}
\hline Source & Sum of Squares & Df & Mean Square & F-Ratio & P-Value \\
\hline Between groups & $5.09219 \mathrm{E} 9$ & 4 & $1.27305 \mathrm{E} 9$ & 13.51 & 0.0000 \\
Within groups & $8.2456 \mathrm{E} 10$ & 875 & $9.42355 \mathrm{E} 7$ & & \\
Total (Corr.) & $8.75482 \mathrm{E} 10$ & 879 & & & \\
\hline
\end{tabular}

Note: Since the P-value of the F-test is less than 0.05 , there is a statistically significant difference between the average wages of the five age groups at the $95.0 \%$ confidence level.

Source: CZSO, authors' calculations

Table 3: The results of Kruskal-Wallis Test

\begin{tabular}{l|rr}
\hline Age groups & Sample Size & Average Rank \\
\hline Less than 30 years & 176 & 304.724 \\
30 - 39 years & 176 & 492.111 \\
40 - 49 years & 176 & 475.116 \\
50 - 59 years & 176 & 437.955 \\
60 years and over & 176 & 492.594 \\
\hline
\end{tabular}

Note: Test statistic $=68.1513$, P-Value $=<0.0001$. Since the P-value is less than 0.05 , there is a statistically significant difference amongst the medians of wages at the $95.0 \%$ confidence level.

Source: CZSO, authors' calculations

This result confirms the previous results from ANOVA methods. The final conclusion is that ANOVA method and Kruskall-Wallis test confirmed statistically significant difference between the level of wages in five age groups.

The situation is quite different when we tested the same hypothesis for each industry separately. We reject hypothesis $\mathrm{H}_{0}$ that the level of wages in five age groups is equal at $\alpha=0.05$ for all industries. The situation is not the same inside each industry. We applied Multiple Range Tests for our data. The results of Multiple Range Tests for selected industries are shown in Table 4. It shows a multiple comparison procedure to determine which means are significantly different from which others. Middle column portrays average wage for period 2005-2015 in particular age groups. The number of homogeneous groups are identified using 
columns of X's. Within each column, the levels containing X's form a group of means within which there are no statistically significant differences.

The differences in level of average wages are evident in all selected industries. The agriculture, forestry and fishing (A), total industry (B-E), information and communication (J) and public administration and defense $(\mathrm{O})$ are selected for demonstration these differences. The Multiple Range Test has detected only 2 homogeneous groups in industry of agriculture (A). Only the difference in wages in the age group less than 30 years is noticeable, the other age groups are homogeneous in terms of the average wage for the period 2005-2015. In the total industry (B-E), the average wage of employees in age group 30-49 years is on the same level, with the highest average wage for employees older than 60 years.

Table 4: The results of Multiple Range Tests for selected industries

\begin{tabular}{l|lc}
\hline \multicolumn{1}{c|}{ A } & Mean & $\begin{array}{c}\text { Homogeneous } \\
\text { Groups }\end{array}$ \\
\hline Less than 30 years & 18493.2 & $\mathrm{X}$ \\
30 - 39 years & 20500.2 & $\mathrm{X}$ \\
40 - 49 years & 20472.2 & $\mathrm{X}$ \\
50 - 59 years & 19837.2 & $\mathrm{X}$ \\
60 years and over & 19813.7 & $\mathrm{X}$ \\
\hline
\end{tabular}

\begin{tabular}{l|cc}
\hline \multicolumn{1}{c|}{ B-E } & Mean & $\begin{array}{c}\text { Homogeneous } \\
\text { Groups }\end{array}$ \\
\hline Less than 30 years & 21232.3 & $\mathrm{X}$ \\
$30-$ 39 years & 26208.0 & $\mathrm{X}$ \\
$40-49$ years & 26039.9 & $\mathrm{X}$ \\
$50-59$ years & 24598.2 & $\mathrm{X}$ \\
60 years and over & 27872.2 & $\mathrm{X}$
\end{tabular}

\begin{tabular}{l|lc}
\hline \multicolumn{1}{c|}{$\mathrm{J}$} & Mean & $\begin{array}{c}\text { Homogeneous } \\
\text { Groups }\end{array}$ \\
\hline Less than 30 years & 32857.6 & $\mathrm{X}$ \\
30 - 39 years & 48248.9 & $\mathrm{X}$ \\
40 - 49 years & 50482.7 & $\mathrm{X}$ \\
50 - 59 years & 42992.6 & $\mathrm{X}$ \\
60 years and over & 41912.4 & $\mathrm{X}$ \\
\hline
\end{tabular}

\begin{tabular}{l|cc}
\hline \multicolumn{1}{c|}{$\mathrm{O}$} & Mean & $\begin{array}{c}\text { Homogeneous } \\
\text { Groups }\end{array}$ \\
\hline Less than 30 years & 25884.0 & $\mathrm{X}$ \\
30 - 39 years & 31903.8 & $\mathrm{X}$ \\
40 - 49 years & 33912.5 & $\mathrm{X}$ \\
50 - 59 years & 34239.6 & $\mathrm{X}$ \\
60 years and over & 36429.4 & $\mathrm{X}$ \\
\hline
\end{tabular}

Note: The method being used to discriminate among the means is Fisher's least significant difference (LSD) procedure. With this method, there is a $5.0 \%$ risk of calling each pair of means significantly different when the actual difference equals 0 .

Source: CZSO, authors' calculations

Interesting results brings the view on wage structure by age in sector of services. The results in industry information and communication $(\mathrm{J})$ show the highest average wages between 30-49 years and falling them over 50 years of age. This corresponds to the hypothesis Skirbekk (2004) on the declining ability to adopt of new technologies and computers of workers around 50 years of age. In the future, however, it can be assumed that the number of older employees able to use modern technology will increase as today they learn from their youth. On the contrary, average wages are increasing with age in public administration $(\mathrm{O})$. In the group of employees aged over 60 years, the highest average wage is evident in 2005-2015. It may indicate that population ageing will have positive effects in this industry. This industry takes advantage of the workers with years of experience, as demonstrated the analysis by Posner (1995) of the increasing labour productivity of judges with age.

\subsection{Gross value added by age of employees}

Total gross value added was 4095 CZK billion in the Czech Republic in 2015. Since 2005, GVA at current prices has increased 1.3 times (measured at prices of 2015, it has increased 1.1 times). GVA (at prices of 2015) created by employees younger than 29 years was by 
$14.2 \%$ lower in 2015 compared to 2005 . On the contrary, GVA created by employees older than 60 years was by $104.5 \%$ higher in 2015 in comparison to 2005. This undoubtedly indicates an increasing number of older employees. According our estimates, employees in age group from 40 to 49 years have the largest share on generated value added, see Figure 4. This age category of employees contributed to GVA 30.0\% in 2015. Employees older than 60 years contributed to GVA by $7.4 \%$, which is by 3.3 p.p. higher share compared to 2005 . Contribution of employees younger than 29 years to GVA has decreased over time, from $16.8 \%$ in 2005 to $12.7 \%$ in 2015 .

Figure 4: Composition of gross value added by age groups in 2005 and 2015 (\%, current prices)

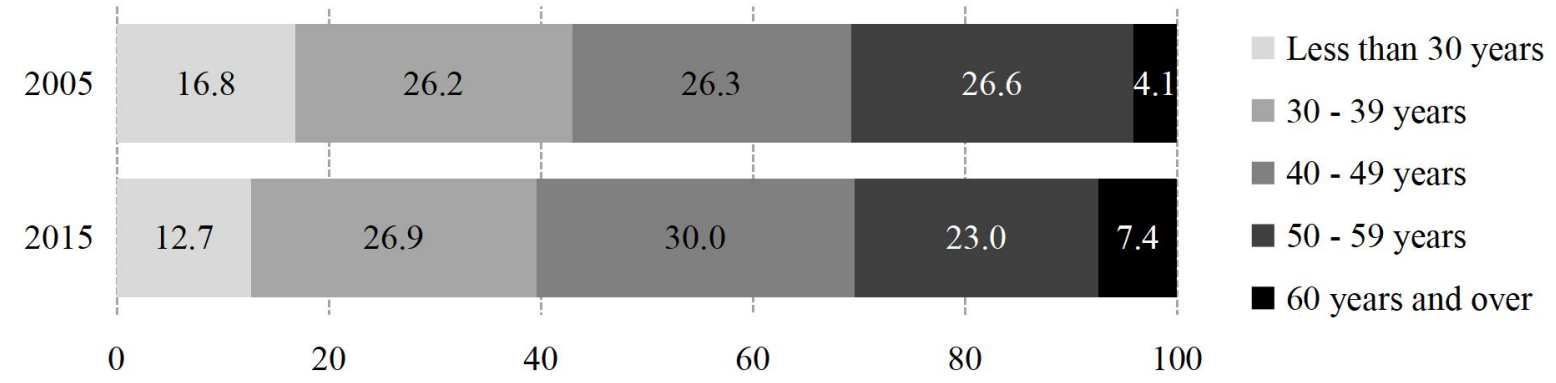

Source: CZSO, authors' calculations

More appropriate measure of the contribution of particular age groups of employees to GVA is labour productivity, i.e. the share of GVA per employee. We do not have enough information about self-employed by age, so we calculate labour productivity per employee (Vltavská, 2011). The calculation is provided in real terms, i.e. GVA is recalculated to constant prices of the year 2015.

Figure 5: Labour productivity by age groups (prices of 2015, thousand CZK)

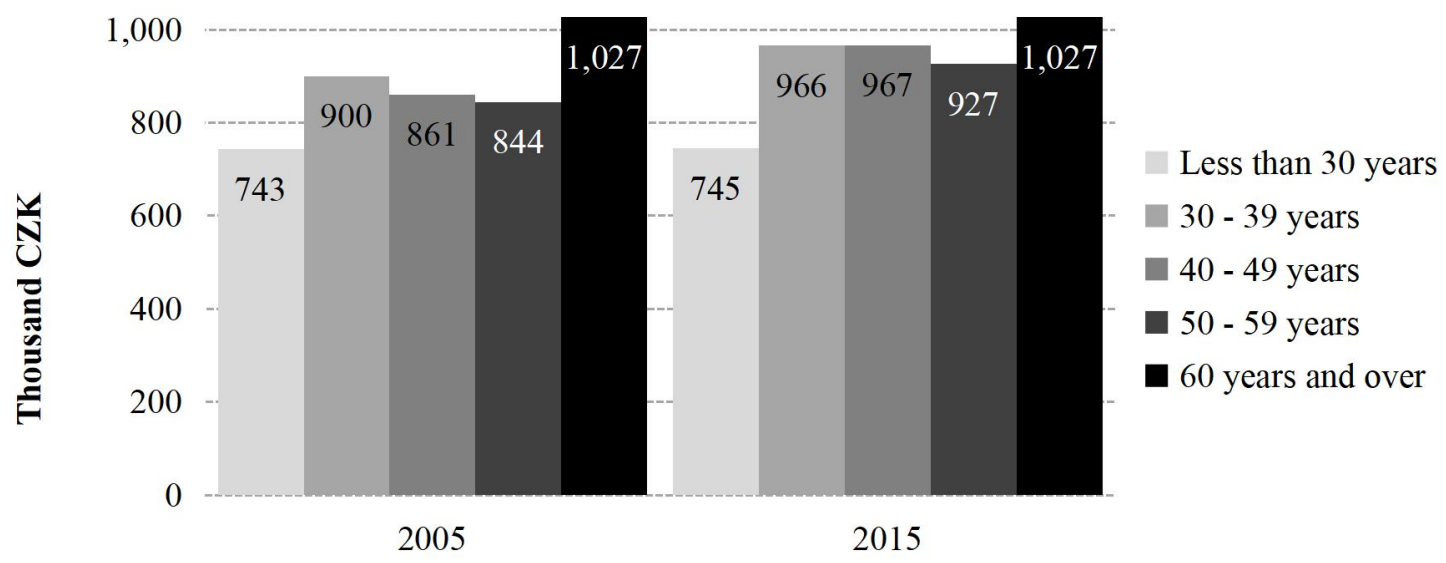

Source: CZSO, authors' calculations

Generally, GVA per employee increased between 2000 and 2015 by $9 \%$. The most significant increase is observed in age group of employees between 40-49 years. However, as shown in Figure 5, labour productivity of employees younger than 30 years is at the same level as labour productivity of employees older than 60 years. These figures do not confirm the idea of possible negative effect of age on GVA. In other words, up to now population ageing does not cause a decline in generated value added and output. However, it is necessary 
to focus on individual industries. The following Table 5 shows GVA per employee by age in selected industries in 2000 and 2015 and its change during this decade.

Labour productivity of employees younger than 30 years has increased between 2005 and 2015 in agriculture (A) by $12.4 \%$ and in total industry (B-E) by $19.1 \%$. But it has decreased by $11.4 \%$ in information and communication $(\mathrm{J})$. Public administration $(\mathrm{O})$ has had no significant change in labour productivity of employees younger than 30 years. Employees of age 40-49 years have more than 20\% higher labour productivity in 2015 compared to 2005 in total industry (B-E) and information and communication $(\mathrm{J})$. In public administration $(\mathrm{O})$, labour productivity of employees aged $40-49$ years is higher by $12.5 \%$ and in agriculture only by $6.5 \%$. The highest increase in labour productivity of employees older than 60 years has been seen in public administration (O) during 2005-2015. Slight increase was in agriculture (by $6.2 \%$ ) and total industry (by 9.4\%). On the contrary, the modest decrease of labour productivity of employees older than 60 years was information and communication $(2.9 \%)$. These figures correspond with figures in the previous chapter. Similarly to the study written by Mahlberg et al. (2013), our results show that the higher labour productivity goes along with the increase age of employees in some industries.

Table 5: The development of labour productivity by age groups in selected industries between 2005 and 2015 (prices of 2015, thousand CZK)

\begin{tabular}{l|l|rrrr}
\hline \multicolumn{2}{l}{} & \multicolumn{1}{c}{ A } & \multicolumn{1}{l}{ B-E } & J & \multicolumn{1}{l}{ O } \\
\hline \multirow{4}{*}{$\mathbf{2 0 0 5}$} & Less than 30 years & 753 & 654 & 1456 & 669 \\
& $\mathbf{3 0}-\mathbf{3 9}$ years & 841 & 811 & 1741 & 780 \\
& $\mathbf{4 0}-\mathbf{4 9}$ years & 848 & 814 & 1653 & 810 \\
& $\mathbf{5 0}-\mathbf{5 9}$ years & 825 & 788 & 1604 & 825 \\
& 60 years and over & 884 & 963 & 1685 & 851 \\
\hline \multirow{5}{*}{$\mathbf{2 0 1 5}$} & Less than 30 years & 846 & 779 & 1290 & 664 \\
& $\mathbf{3 0}-\mathbf{3 9}$ years & 892 & 988 & 1903 & 855 \\
& $\mathbf{4 0}-\mathbf{4 9}$ years & 902 & 1004 & 2011 & 911 \\
& $\mathbf{5 0}-\mathbf{5 9}$ years & 931 & 969 & 1672 & 909 \\
& 60 years and over & 939 & 1053 & 1636 & 954 \\
\hline \multirow{5}{*}{$\mathbf{I}_{\mathbf{2 0 1 5} / 2005}$} & Less than 30 years & 1.124 & 1.191 & 0.886 & 0.993 \\
& $\mathbf{3 0}-\mathbf{3 9}$ years & 1.061 & 1.219 & 1.093 & 1.096 \\
& $\mathbf{4 0}-\mathbf{4 9}$ years & 1.065 & 1.234 & 1.216 & 1.125 \\
& $\mathbf{5 0}-\mathbf{5 9}$ years & 1.128 & 1.231 & 1.042 & 1.102 \\
& 60 years and over & 1.062 & 1.094 & 0.971 & 1.121 \\
\hline
\end{tabular}

Source: CZSO, authors' calculations

\section{Conclusion}

Population ageing is connected with many different areas ranging from availability of skilled labour force to availability of social services for old people. Within economic consequences of population ageing, we focused on the supply side of the economy. The research done in Western countries provided inspiration for us, because this issue has not been seriously discussed in the Czech Republic up to now. Detailed information about the labour productivity of employees by age and their contribution to the value added of a company can provide useful information for the management of companies as well as for construction of social policies for population ageing at country level. It is important to identify the weak spots of the economy springing from population ageing. 
Following the analysis in Šimková, Sixta (2016) we prepared the distribution of wages and value added by age in the Czech economy accompanied by statistical testing of significance of differences among age groups. The results shows that cannot be found generalised conclusions for the Czech Republic, similarly to Western countries. The distribution of gross value added by industries illustrates that the impacts on industries are different. The differences between age groups are clearly visible. Higher labour productivity as well as higher level of average wages of older employees positively stimulates some industries. In some industries increasing number of older employees does not decrease outcome and labour productivity (e.g. total industry, public administration or business services except IT).

The deep study of economic impacts of population ageing on the economy is necessary. It would be optimal to focus on population ageing and find specific approach to different industries in government ageing policy.

\section{Acknowledgements}

This paper was written with the support of the Czech Science Foundation project No. P402/12/G097 „DYME - Dynamic Models in Economics“ and with the support of Institutional Support for Long Period and Conceptual Development of Research and Science at Faculty of Informatics and Statistics, University of Economics, Prague.

\section{References}

[1] Avolio, B. J., \& Waldman, D. A. 1994. Variations in cognitive, perceptual, and psychomotor abilities across the working life span: Examining the effects of race, sex, experience, education, and occupational type. Psychology and Aging, 9, 430-442.

[2] Bhattacharya, M., Smyth, R. 2001. Aging and productivity among judges: some empirical evidence from the high court of Australia. Australian Economic Papers 40: 199-212.

[3] Diamond, A. 1986. The Life-Cycle Research Productivity of Mathematicians and Scientists. Journal of Gerontology 41: 520-525.

[4] Elgin, C., Kuzubas, T. U. 2013. Wage-Productivity Gap in OECD Economies. Economics: The Open-Access, Open-Assessment E-Journal, 7(21): 1-21.

[5] Eurostat. 2013. European System of Accounts (ESA 2010). Eurostat, Luxembourg 2013.

[6] Fiala, T., Langhamrová, J. 2016. Vývoj indexu závislosti seniorů při navrhované změně důchodového věku a různých variantách demografického vývoje. Fórum sociální politiky. 2016, roč. 10, č. 6, s. 27-32. ISSN 1802-5854.

[7] Göbel, C., Zwick, T. 2010. Which personnel measures are effective in increasing productivity of older workers? Discussion Paper No. 10-069, Centre for European Economic Research.

[8] Kuckulenz, A. 2006. Wage and productivity effect of continuing training in Germany: a sectoral analysis. Discussion Paper 06-025, Centre for European Economic Research.

[9] Leuprecht, Ch. 2010. Defending Democracy and Securing Diversity. London: Routledge. 76: 103-118.

[10] Mahlberg, B., Freund, I., Prskawetz, A. 2013. Ageing, productivity and wages in Austria: sector level evidence. Empirica 40: 561-584

[11] Oster, S. M., Hamermesh, D. S. 1998. Aging and Productivity among Economists. The Review of Economics and Statistics 80(1): 154-156.

[12] Posner, R. 1995. Aging and Old Age. University of Chicago Press, Chicago.

[13] Prskawetz, A., Fent, T., Barthel, W., Crespo-Cuaresma, J., Lindh, T., Malmberg, B., Halvarsson, M. 2007. The relationship between demographic change and economic 
growth in the EU. Research Report No. 32, Vienna Institute for Demography, Austrian Academy of Science.

[14] Průša, L. 2015. Důsledky stárnutí populace na potřebu služeb sociální péče do roku 2030. Demografie 2015, roč. 57, č. 3, s. 231-244. ISSN 0011-8265.

[15] Sivák, R., Ochotnický, P., Čambalová, A. 2011. Fiškálna udržatel’nost’ penzijných systémov. Politická ekonomie 2011, 59 (6), s. 723-742. ISSN 0032-3233.

[16] Sixta, J. Vltavská, K. 2016. Změny v měření ekonomiky a dopady do odhadu produktivity. Politická ekonomie 2016, roč. 64, č. 3, s. 351-368. ISSN 0032-3233.

[17] Skirbekk, V. 2004. Age and individual productivity: A literature survey. Vienna, Austria: Vienna Yearbook of Population Research, Verlag der Osterreichischen Akademie der Wissenschaften.

[18] Šídlo, L. 2011. Stárnutí lékařư primární zdravotní péče v České republice. Demografie, roč. 53, č. 3, s. 203-213.

[19] Šimková, M., Sixta, J. 2016. Ageing of labour force and productivity growth in the Czech Republic. In: Applications of Mathematics and Statistics in Economics. Banská Štiavnica, 31.08.2016 - 04.09.2016. s. 350-358. ISBN 978-80-89438-04-4.

[20] Tang, J., Macleod, C. 2006. Labour Force Ageing and Productivity Performance in Canada. The Canadian Journal of Economics 39(2): 582-603. 76(1): 103-118.

[21] Vltavská, K. 2011. Estimation of Total Factor Productivity: Comparison of the Possible Approaches and the Different Inputs. In: Proceedings of the Finance and Economics Conference 2011, s. 98-103. ISSN 2190-7935. 


\section{Annex: European Classification of Economic Activities (NACE)}

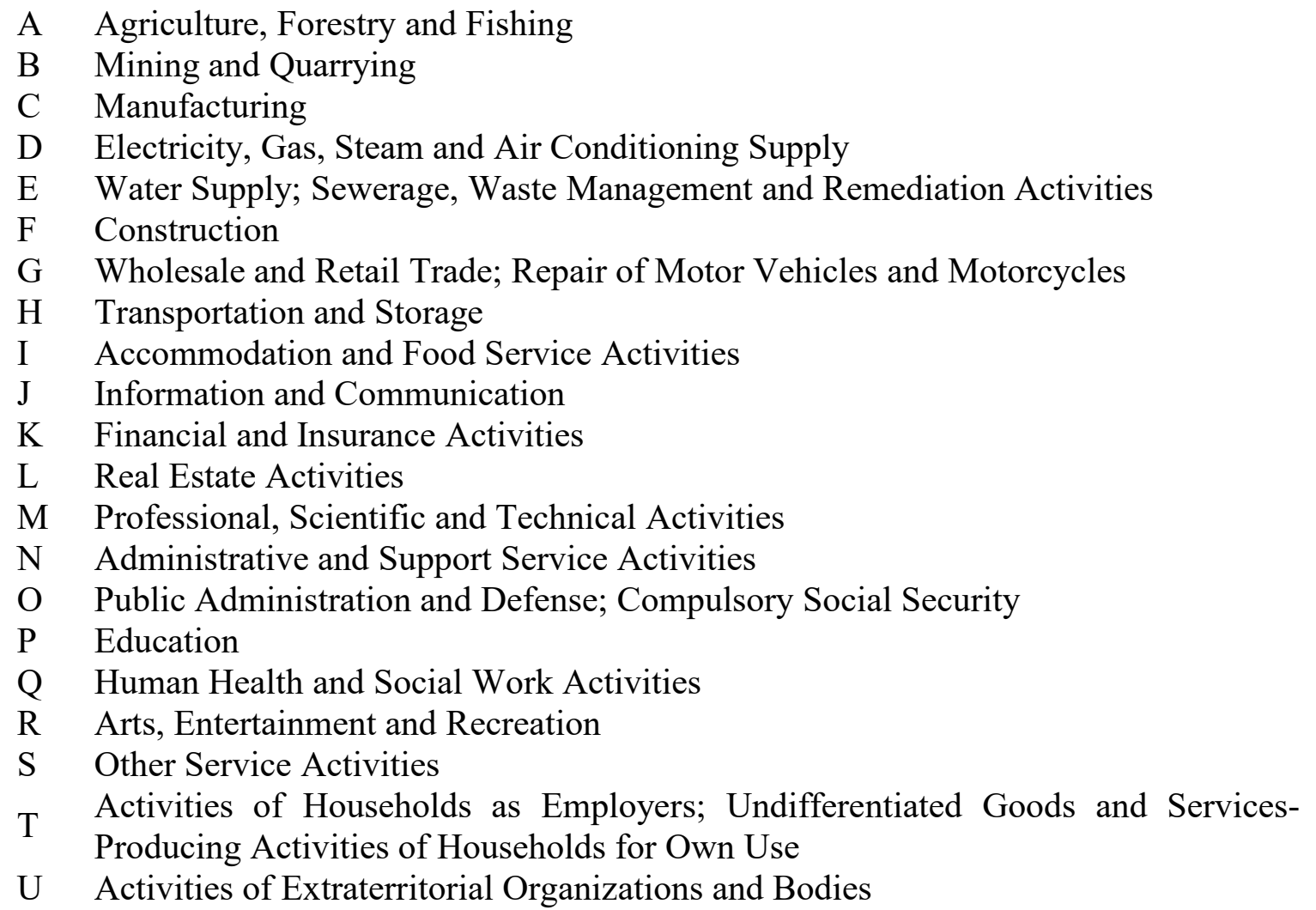

